\title{
UJI KEAKURATAN DATA GFS MENGGUNAKAN MODEL WRF-ARW PADA SIKLON TROPIS FLAMBOYAN
}

\author{
RAHMATIA DEWI ARIYANTI, FATIMAH MEGA SUGIHARTATI, WINDA \\ RETHATARANITA*, PAULUS AGUS WINARSO \\ Prodi Meteorologi, \\ Sekolah Tinggi Meteorologi Klimatologi dan Geofisika \\ Jl. Perhubungan 1 No.5, Pondok Betung, Pondok Aren, Tangerang Selatan, Banten 15221 \\ *email : windarethataranita@yahoo.co.id
}

\begin{abstract}
Abstrak.Siklon Tropis dapat menyebabkan cuaca buruk berupa angin kencang, gelombang tinggi maupun hujan lebat. Keberadaan siklon tropis dapat diprakirakan menggunakan data Global Forecast System (GFS) yang diolah dengan model Weather Research Forcasting-Advance Research WRF (WRF -ARW). Uji keakuratan data GFS perlu dilakukan salah satunya terhadapsiklon tropis Flamboyan agar dapat digunakan sebagai acuan dalam memprediksi keberadaan siklon tropis kedepannya. Hasil analisis tanggal 28 April 2018 pukul 12.00 UTC menunjukkan nilai suhu permukaan laut (SPL) di sekitar wilayah pembentukan siklon tropis bernilai $29-30^{\circ} \mathrm{C}$ dan terjadi penurunan tekanan permukaan mencapai $1000 \mathrm{mb}$ pada tanggal 29 April 201800.00 UTC. Kelembaban udara bernilai $80-100 \%$ pada lapisan $850 \mathrm{mb}$, lapisan $700 \mathrm{mb}$ bernilai 70 - $100 \%$ dan lapisan $500 \mathrm{mb}$ bernilai 60 - 90\%. Streamline lapisan $925 \mathrm{mb}$ menunjukkan adanya pusaran angin searah jarum jam yang mengindikasikan adanya siklon tropis. Vortisitas dan divergensi lapisan $850 \mathrm{mb}$ bernilai negatif $20-60 \times 10^{-5} \mathrm{~s}^{-1}$ dan negatif $15-30 \times 10^{-5} \mathrm{~s}^{-1}$ serta lapisan $500 \mathrm{mb}$ bernilai negatif $20-50 \times 10^{-5} \mathrm{~s}^{-1}$ dan negatif $15-25 \times 10^{-5} \mathrm{~s}^{-1}$. Suhu puncak awan di wilayah siklon tropis kurang dari $-40^{\circ} \mathrm{C}$ mengindikasikan adanya awan Cumulonimbus. Hal tersebut sesuai dengan syarat pertumbuhan siklon tropis sehingga data GFS dinyatakan akurat dalam memprediksi kehadiran siklon tropis Flamboyan.
\end{abstract}

Kata kunci: WRF-ARW, GFS, Siklon

Abstract. Tropical cyclones can cause bad weather like gusty, high waves or heavy rain. Existence of tropical cyclones can be predicted using Global Forecast System data which processed with Weather Research Forecasting-Advance Research WRF. Accuracy test of GFS data in tropical cyclone flamboyan are necessary to be used as reference in predicting tropical cyclones in the future. Analysis results on April $28^{\text {th }}$, 2018 at 12.00 UTC shows sea surface temperature in region of tropical cyclone growth is $29-30^{\circ} \mathrm{C}$ and a decrease in surface pressure up to $1000 \mathrm{mb}$ until on April $29^{\text {th }}, 2018$ at 00.00 UTC. Relative humidity is $80-100 \%, 70-100 \%$ and $60-90 \%$ at $850 \mathrm{mb}, 700 \mathrm{mb}$ and $500 \mathrm{mb}$ layer. Streamline at $925 \mathrm{mb}$ layer shows existence of wind whirl clockwise which indicates presence of tropical cyclones. Vortices and divergences at $850 \mathrm{mb}$ layers are negative $20-60 \times 10^{-5} \mathrm{~s}^{-1}$ and negative $15-30 \times 10^{-5} \mathrm{~s}^{-1}$ and at $500 \mathrm{mb}$ layer are negative $20-50 \times 10^{-5} \mathrm{~s}^{-1}$ and negative $15-25 \times 10^{-5} \mathrm{~s}^{-1}$. Cloud top temperatures in tropical cyclone region is less than $-40^{\circ} \mathrm{C}$ that indicates presence of Cumulonimbus clouds. This is in accordance with requirements of tropical cyclone growth so that, GFS data is accurate to predicting presence of tropical cyclones Flamboyan.

Keywords: WRF-ARW, GFS, Cyclone 


\section{Pendahuluan}

Siklon Tropis Flamboyan merupakan siklon tropis ke enam yang tumbuh di wilayah tanggung jawab Tropical Cyclone Warning Center (TCWC) Jakarta. Berdasarkan berita dari detik.com, BMKG mengatakan bahwa siklon tropis Flamboyan tumbuh di Samudera Hindia bagian Barat Daya Sumatera dengan pergerakan ke arah Barat Daya - Barat dengan kecepatan $9 \mathrm{~km} / \mathrm{jam}$ menjauhi wilayah Indonesia. Siklon tropis ini berdampak pada kondisi cuaca di Indonesia, terutama terhadap tingginya gelombang laut di perairan Bengkulu hingga Perairan di selatan Pulau Jawa.

Untuk memprediksi keberadaan siklon tropis kedepannya, perlu dilakukan prediksi cuaca salah satunya terhadap siklon tropis Flamboyan. Prediksi ini menggunakan data Global Forecast System (GFS) dimana keakuratan data ini masih harus diuji menggunakan model Weather Research Forcasting-Advance Research WRF (WRF -ARW). WRF-ARW adalah model cuaca yang dapat digunakan untuk melakukan prediksi atmosfer skala menengah dan mengasimilasikan hasil prediksi tersebut dengan data observasi lokal[1]. Model cuaca WRF ini sangat cocok untuk dikembangkan sebagai pemodelan cuaca mendasar di Indonesia karena telah digunakan sebagai dasar prediksi oleh seluruh konstituen yang terkait dengan prediksi cuaca di Amerika Serikat serta telah diadopsi dan dikembangkan oleh negara lain. GFS merupakan data yang berisi model spektral untuk prediksi cuaca global yang dijalankan oleh National Centerfor Environmental Prediction (NCEP)[2].

Penelitian ini bertujuan untuk menguji keakuratan data GFS dalam memprediksi kehadiran siklon tropis di wilayah tanggung jawab TCWC Jakarta. Penelitian ini perlu dilakukan untuk mengantisipasi dampak yang ditimbulkan akibat adanya siklon tropis di masa yang akan datang. Siklon tropis yang digunakan dalam penelitian ini adalah siklon tropis Flamboyan yang terjadi tanggal 28 April 2018. Parameter yang akan dianalisis berupa Sea Surface Temperature (SST), tekanan permukaan laut, kelembaban lapisan $850 \mathrm{mb}$ hingga $500 \mathrm{mb}$, angin lapisan $925 \mathrm{mb}$ hingga $300 \mathrm{mb}$, divergensi, vortisitas, dan suhu puncak awan dengan interval waktu 6 jam.

\section{Metode Penelitian}

\subsection{Lokasi Peneletian}

Lokasi penelitian yang dilakukan terletak di Samudera Hindia bagian barat daya Sumatera Selatan dengan koordinat $0-15$ Lintang Selatan dan $85-100$ Bujur Timur. 


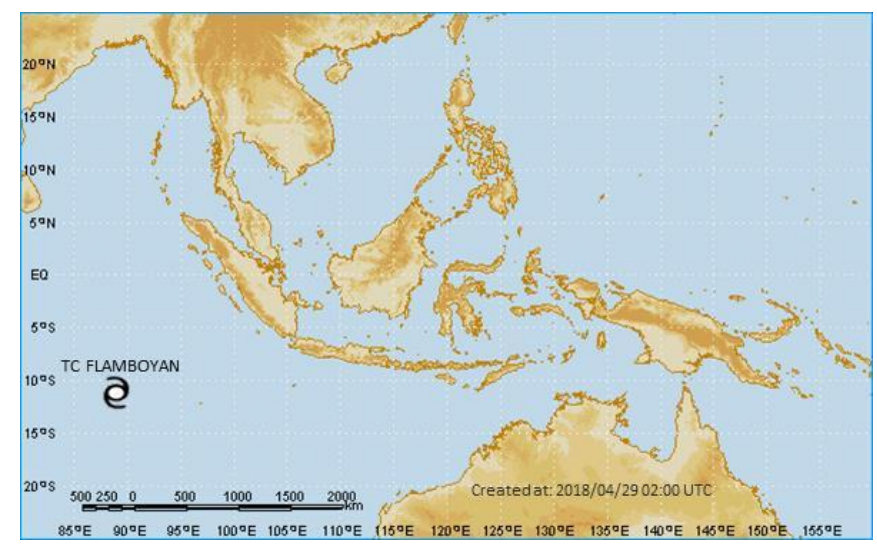

Gambar 1. Peta Lokasi Siklon Tropis Flamboyan Sumber: BMKG Jakarta

\subsection{Data Penelitian}

Data yang digunakan dalam penelitian adalah:

a. Data Global Forecast System (GFS) dari National Center forAtmospheric Research (NCEP-NCAR) resolusi $0.25^{0} \times 0.25^{\circ}$ tanggal 28 April 2018 pukul 12.00 UTC hingga 29 April 2018 pukul 00.00 UTC dengan interval waktu 6 jam.

b. Data Satelit dari BMKG dengan format .nc tanggal 28 April 2018 pukul 12.00 UTC hingga 29 April 2018 pukul 00.00 UTC dengan interval waktu 6 jam.

\subsection{Metodologi Penelitian}

a. Mendownload data GFS pada tanggal 28 April 2018 pukul 12.00 UTC hingga tanggal 29 April 2018 pukul 00.00 UTC dengan interval waktu 6 jam.

b. Running data GFS dengan model WRF-ARW dimana sebelumnya membuat 2 domain (Gambar 1.) dengan titik di pusat siklon tropis Flamboyan hingga menjadikan data berbasis .ctl dan .dat. Dengan menggunakan konfigurasi yang cocok di koordinat siklon tropis Flamboyan (Tabel 1.)

Tabel 1. Konfigurasi Model WRF-ARW

\begin{tabular}{ccc}
\hline Konfigurasi & Domain 1 & Domain 2 \\
\hline Resolusi Grid Horizontal & $30 \mathrm{Km}$ & $10 \mathrm{Km}$ \\
Skema Mikrofisik & WSM3 & WSM3 \\
Skema PBL & YSU & YSU \\
Skema Parameterisasi & & \\
Cumulus & Kain-Fritsch & Kain-Fritsch \\
Resolusi Temporal & 180 menit & 60 menit \\
Jumlah Level Vertikal & 32 lapisan & 32 lapisan \\
\hline
\end{tabular}

c. Menganalisis setiap parameter-parameter cuaca yang ada.

d. Menarik kesimpulan. 


\section{Hasil dan Pembahasan}

\subsection{Suhu Permukaan Laut}

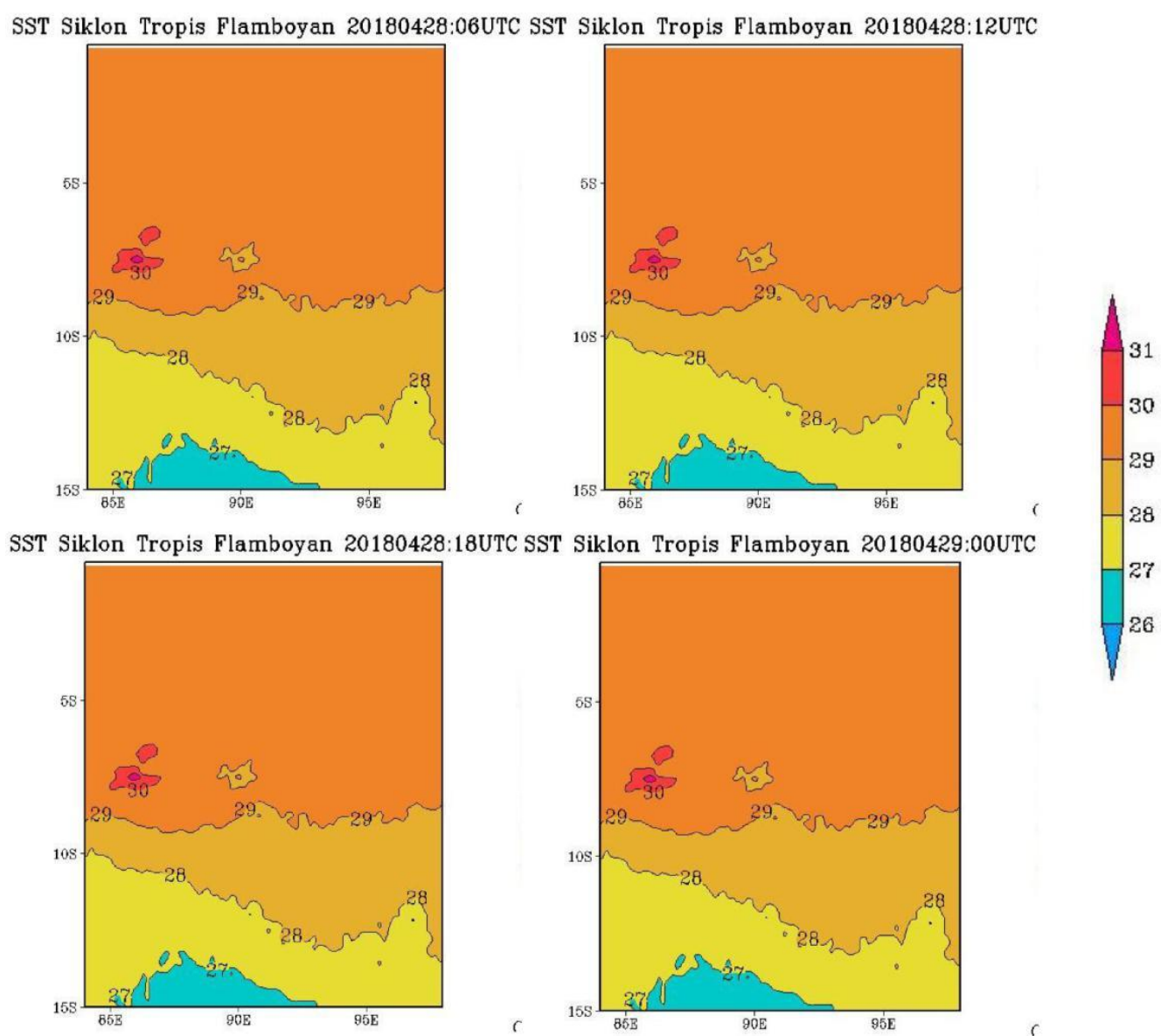

Gambar 2. Suhu permukaan laut tanggal 28 April 2018 pukul 06.00 UTC hingga tanggal 29 April 2018 pukul 00.00 UTC

Suhu permukaan laut merupakan suatu parameter yang dapat digunakan sebagai indikasi pendukung pertumbuhan awan konvektif, dikarenakan pada perairan yang hangat ini mengindikasikan daerah pusat massa udara dari wilayah perairan yang memiliki suhu lebih rendah. Gambar 2 diatas menjelaskan bahwa suhu permukaan laut selama terjadinya siklon tropis Flamboyan ini mulai tanggal 28 April 2018 pukul 06.00 UTC ketika masih dalam keadaan low pressure hingga mulai dinyatakan sebagai siklon tropis Flamboyan pada tanggal 28 April 2018 pukul 12 UTC, kondisi suhu permukaan laut di wilayah pertumbuhan siklon tropis atau sebelah barat daya pulau Sumatera memiliki nilai yang konstan hangat yaitu $29-30^{\circ} \mathrm{C}$. Kondisi perairan yang hangat ini mendukung terbentuknya siklon tropis Flamboyan berdasarkan salah satu syarat tumbuhnya siklon tropis menurut Badan Meteorologi Klimatologi dan Geofisika (BMKG, 2009)[3] dimana siklon tropis merupakan badai berkekuatan besar yang terbentuk di atas lautan luas dengan suhu permukaan air laut hangat lebih dari $26.5^{\circ} \mathrm{C}$. 


\subsection{Tekanan Permukaan}

Tekanan permukaan merupakan salah satu parameter yang penting dalam mengindikasikan keberadaan siklon tropis. Siklon tropis adalah sistem tekanan rendah dengan isobar tertutup [4]. Dalam hal ini, nilai tekanan permukaan mulai tanggal 28 April 2018 pukul 06.00 UTC dimana masih tercatat sebagai lowpressure hingga mulai dinyatakan sebagai siklon tropis Flamboyan pada tanggal 28 April 2018 pukul 12.00 UTC pada wilayah pertumbuhan siklon tropis yaitu sebelah barat daya pulau Sumatera memiliki pola tekanan permukaan yang membentuk lingkaran dengan pusat tekanan permukan bernilai paling rendah serta nilai tekanan permukaan yang semakin menurun mulai tanggal 28 April 2018 pukul 06.00 UTC hingga tanggal 29 April 2018 pukul 00.00 UTC hingga mencapai $1000 \mathrm{mb}$.

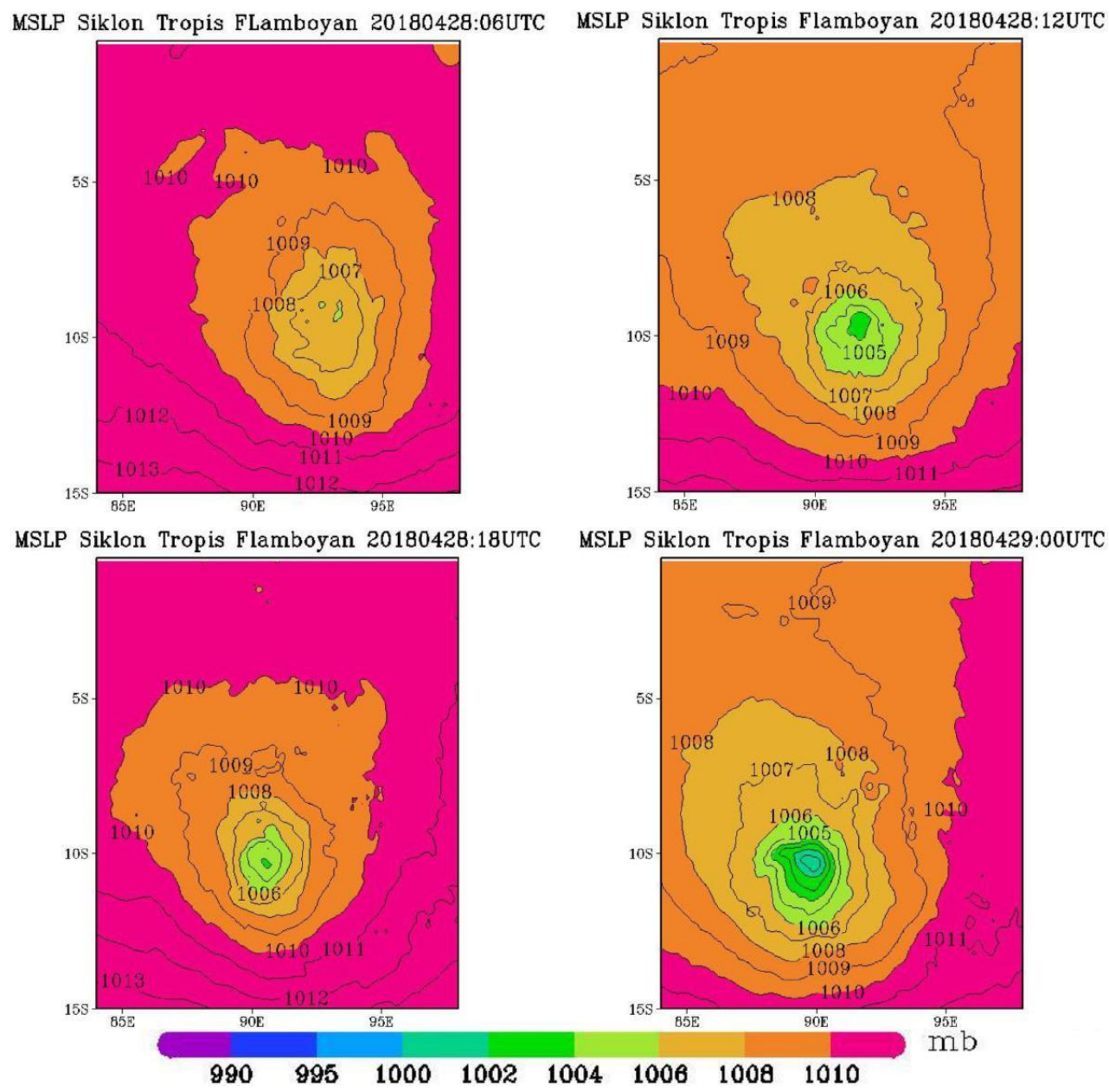

Gambar 3. Tekanan permukaan tanggal 28 April 2018 pukul 06.00 UTC hingga tanggal 29 April 2018 pukul 00.00 UTC

Penurunan nilai tekanan permukaan hingga pola yang membentuk lingkaran ini mendukung bahwa terdapat kejadian siklon tropis dikarenakan siklon tropis yang merupakan sirkulasi tertutup dan memiliki mata siklon yang dapat disebut sebagai pusat siklon tropis. 


\subsection{Kelembaban Udara}

Menurut Seto (2000), kelembaban relatif merupakan persentase kandungan uap air relatif terhadap kandungan maksimal yang dapat dikandung uap air pada temperatur tertentu. Semakin tinggi kelembaban udara semakin baik kondisi atmosfer untuk mendukung pertumbuhan awan[5].

Siklon tropis memberikan dampak pada wilayah yang dilewatinya seperti gelombang tinggi, gelombang badai atau storm surge yang berupa naiknya tinggi muka laut seperti air pasang yang datang secara tiba-tiba, hujan deras serta angin kencang (BMKG, 2009). Perubahan pola cuaca yang terjadi ini disebabkan oleh adanya awan konvektif yang menjulang tinggi seperti awan cumulonimbus. Kelembaban sangat dibutuhkan dalam proses pembentukan awan. Syarat yang mendukung pembentukan awan konvektif antara lain, nilai kelembaban udara pada lapisan signifikan yaitu $850 \mathrm{mb}, 700 \mathrm{mb}$ dan $500 \mathrm{mb}$ memiliki nilai lebih besar atau sama dengan $80 \%$, lebih besar atau sama dengan $60 \%$ dan lebih besar atau sama dengan $50 \%$.
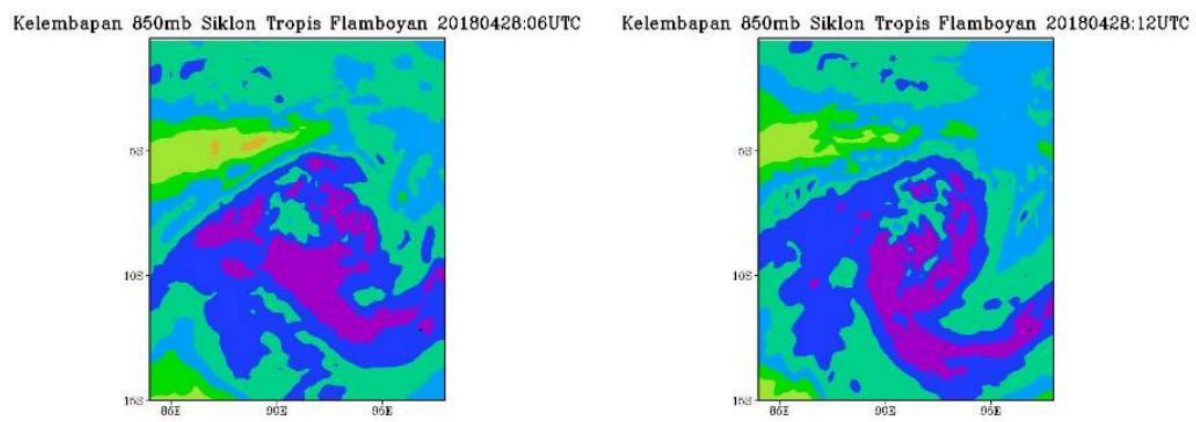

Kelembapan 850mb Siklon Tropis Flamboyan 20180428:18UTC
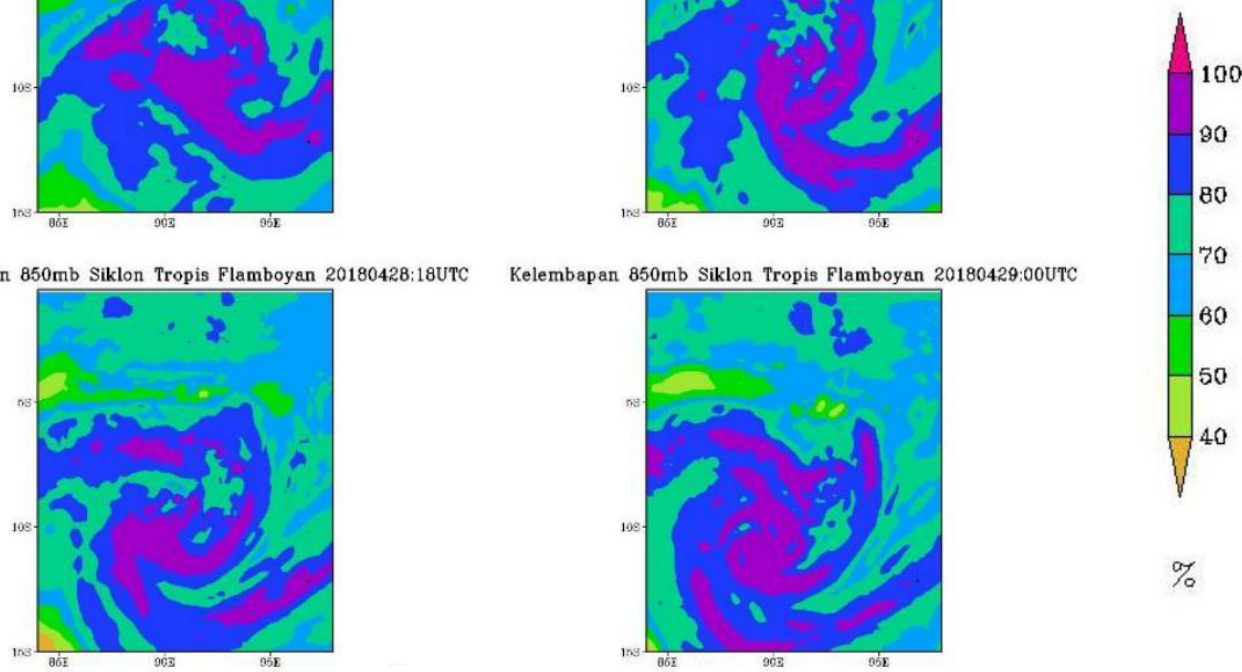

Gambar 4. Kelembaban udara lapisan 850 mb tanggal 28 April 2018 pukul 06.00 UTC hingga tanggal 29 April 2018 pukul 00.00 UTC 
Kelembapan 700mb Siklon Tropis Flamboyan 20180428:06UTC
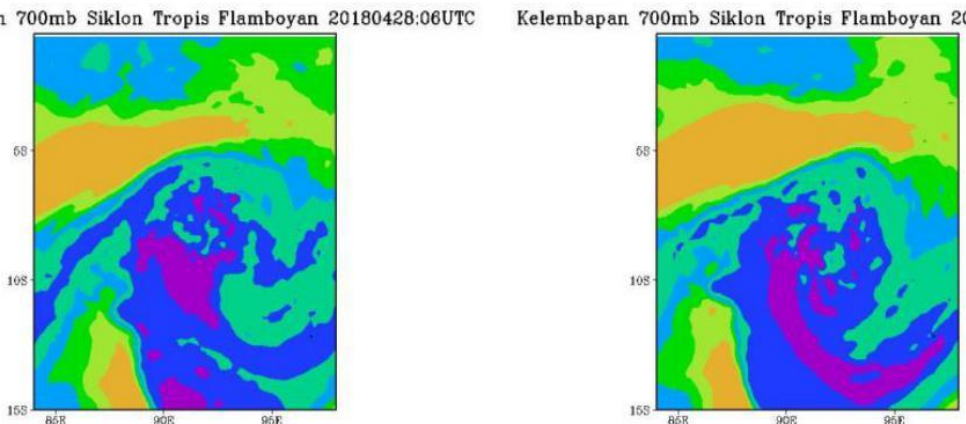

Kelembapan 700mb Siklon Tropis Flamboyan 20180429:00UTC
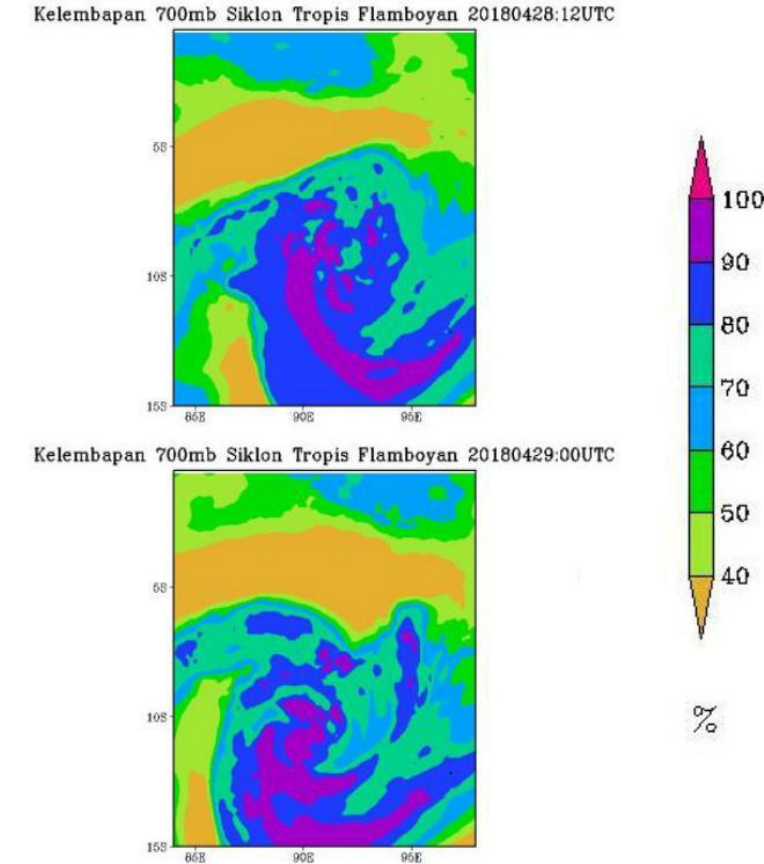

Kelembapan 700mb Siklon Tropis Flamboyan 20180428:18UTC

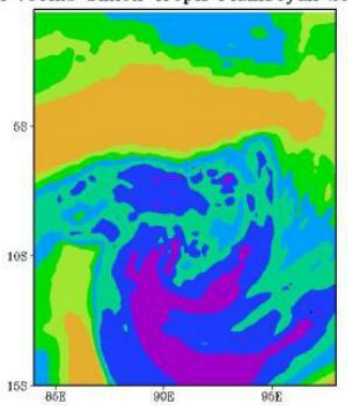

Gambar 5. Kelembaban udara lapisan 700 mb tanggal 28 April 2018 pukul 06.00 UTC hingga tanggal 29 April 2018 pukul 00.00 UTC

Kelembapan 500mb Siklon Tropis Flamboyan 20180428:06UTC

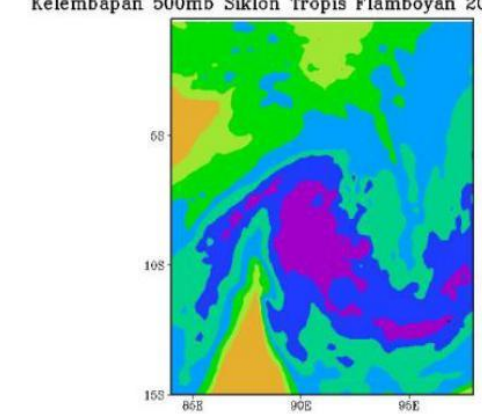

Kelembapan 500mb Siklon Tropis Flamboyan 20180428:12UTC

Kelembapan 500mb Siklon Tropis Flamboyan 20180428:18UTC
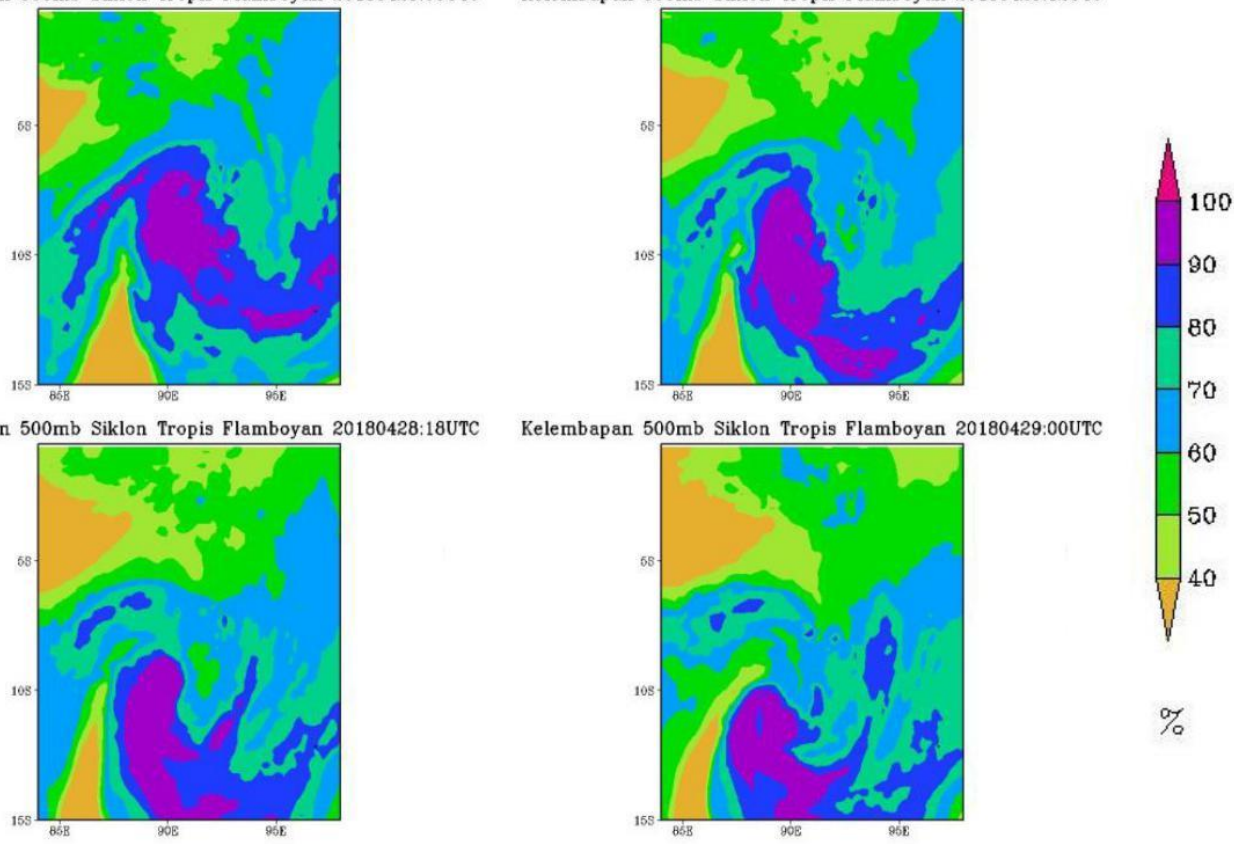

Kelembapan 500mb Siklon Tropis Flamboyan 20180429:00UTC

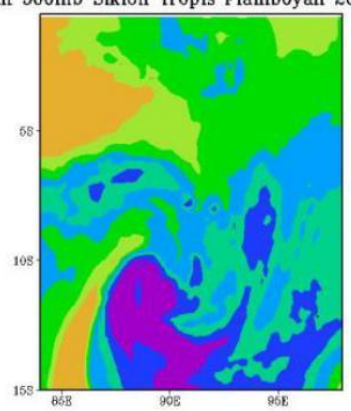

Gambar 6. Kelembaban udara lapisan 500 mb tanggal 28 April 2018 pukul 06.00 UTC hingga tanggal 29 April 2018 pukul 00.00 UTC

Nilai kelembaban udara pada lapisan signifikan dari tanggal 28 April 2018 pukul 06.00 UTC dimana masih dinyatakan sebagai low pressure hingga mulai dinyatakan sebagai siklon tropis Flamboyan pada tanggal 28 April 2018 pukul 12.00 UTC sampai dengan tanggal 29 April 2018 pukul 00.00 UTC memiliki nilai rata-rata sebesar $80-100 \%$ pada lapisan $850 \mathrm{mb}$, lapisan $700 \mathrm{mb}$ bernilai 
70 - 100\% dan lapisan 500 mb bernilai 60 - 90\%. Hasil penelitian ini memiliki nilai kelembaban udara yang tinggi sebagai bahan dasar pembentukan awan konvektif. Pada Gambar 4. sampai Gambar 6 diatas menunjukkan pola kelembaban udara yang membentuk lingkaran atau sirkulasi sebagai bukti bahwa data GFS dapat digunakan untuk merepresentasikan kehadiran siklon tropis Flamboyan dari segi parameter kelembaban udara.

\subsection{Streamline}

Running data GFS dengan model WRF-ARW untuk data angin diperoleh hasil sebagai berikut:
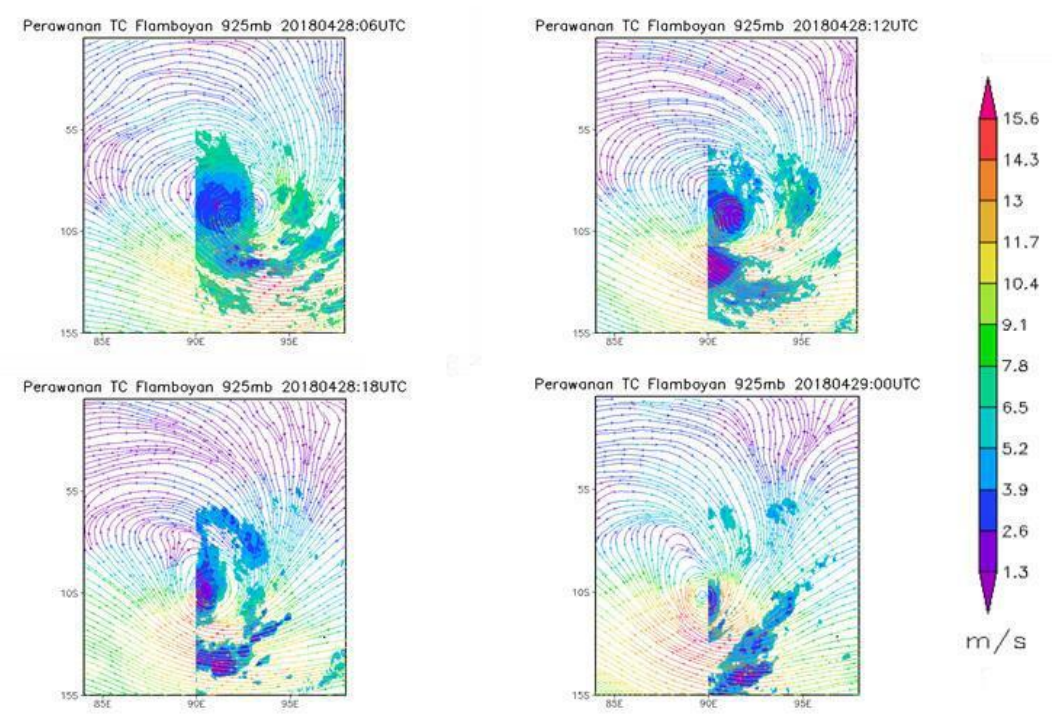

Gambar 7.Overlay Streamline dan Pola Perawanan pada Lapisan $925 \mathrm{mb}$ tanggal 28 April 2018pukul 06.00 UTC hingga 29 April 2018 pukul 00.00 UTC

Angin termasuk parameter penting dalam menganalisis terjadinya siklon tropis. Menurut Zakir dkk (2010), untuk daerah belahan bumi utara (BBU) udara akan berbelok berlawanan dengan arah perputaran jarum jam, sedangkan pada daerah belahan bumi selatan (BBS) udara akan dibelokkan searah jarum jam. Gambar 7. menunjukkan pola angin di titik siklon tropis Flamboyan yang terjadi di wilayah BBS pada tanggal 28 April 2018 pukul 06.00 UTC hingga 29 April 2018 pukul 00.00 UTC di lapisan 925mb, bahwa terjadi pola sirkulasi angin siklonik atau searah dengan jarum jam.

Tanggal 28 April 2018 pukul 06.00 UTC pola siklonik belum terbentuk secara sempurna, masih terdapat dua pola siklonik kecil. Pola siklonik semakin terbentuk sempurna pada tanggal 28 April 2018 pukul 12.00 UTC hingga 29 April 2018 pukul 00.00 UTC. Kecepatan angin di titik pusat bernilai $0-2,6 \mathrm{~m} / \mathrm{s}$. Kecepatan angin meningkat di sekitar titik pusat siklon atau disebut juga dinding siklon tropis, bernilai $9,1-15,6 \mathrm{~m} / \mathrm{s}$. Pola perawanan yang terjadi pada 28 April 2018 pukul 06.00 UTC hingga 29 April 2018 pukul 00.00 UTC menunjukkan pola perawanan siklonik mengikuti pola streamline. 
Gambar 8. menunjukkan pola angin pada tanggal 28 April 2018 pukul 06.00 UTC hingga 29 April 2018 pukul 00.00 UTC di lapisan $850 \mathrm{mb}$, bahwa masih terdapat pola sirkulasi angin siklonik atau searah dengan jarum jam pada lapisan tersebut. Kecepatan angin di titik pusat bernilai $0-10 \mathrm{~m} / \mathrm{s}$. Kecepatan angin meningkat di sekitar titik pusat siklon atau disebut juga dinding siklon tropis, bernilai $10-31 \mathrm{~m} / \mathrm{s}$.
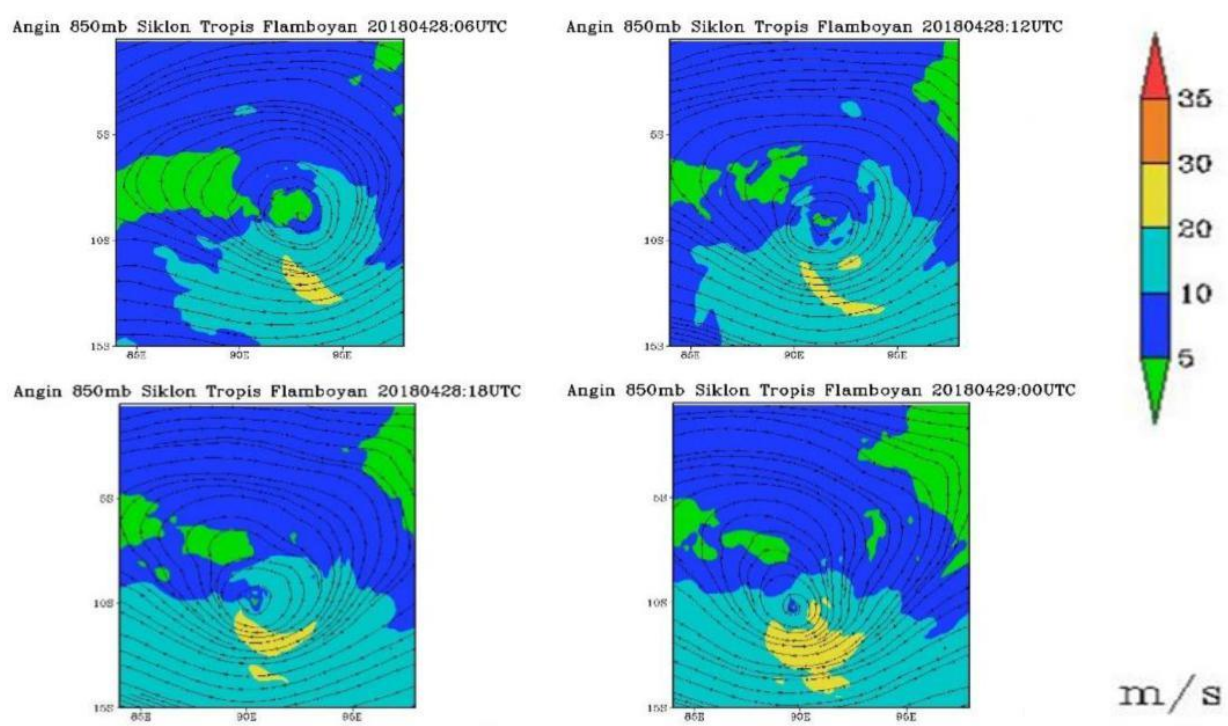

Gambar 8. Streamlinepada Lapisan $850 \mathrm{mb}$ tanggal 28 April 2018 pukul 06.00 UTC hingga 29April 2018 pukul 00.00 UTC
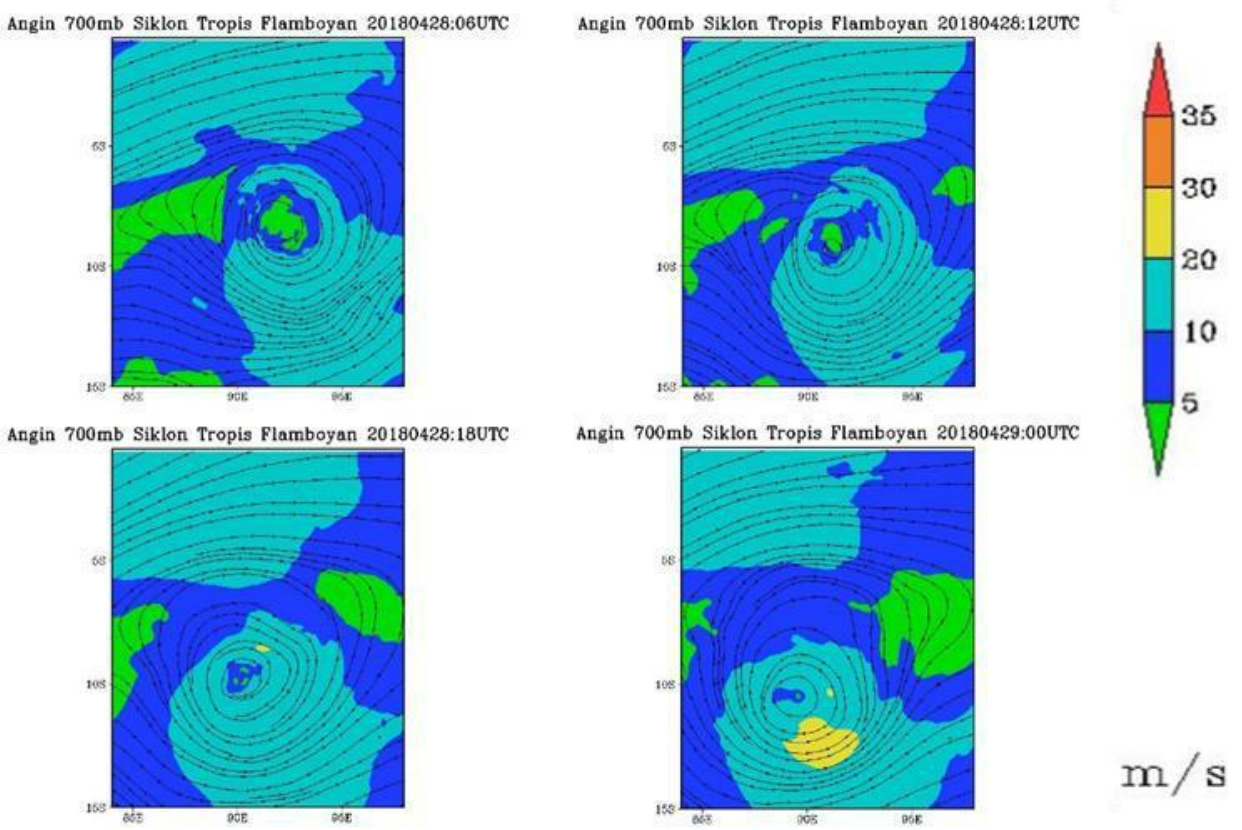

Gambar 9. Streamline pada Lapisan $700 \mathrm{mb}$ tanggal 28 April 2018 pukul 06.00 UTC hingga 29April 2018 pukul 00.00 UTC 
Gambar 9. menunjukkan pola angin di titik siklon tropis Flamboyan yang terjadi di wilayah BBS pada tanggal 28 April 2018 pukul 06.00 UTC hingga 29 April 2018 pukul 00.00 UTC di lapisan 700mb, bahwa masih terdapat pola sirkulasi angin searah dengan jarum jam. Kecepatan angin di titik pusat bernilai $0-10 \mathrm{~m} / \mathrm{s}$. Kecepatan angin meningkat di sekitar titik pusat siklon atau disebut juga dinding siklon tropis. Tanggal 28 April 2018 pukul 06.00 hingga pukul 12.00 UTC kecepatan angin di dinding siklon tropis Flamboyan bernilai $5-10 \mathrm{~m} / \mathrm{s}$. Kecepatan angin di dinding siklon tropis Flamboyan meningkat pada tanggal 28 April 2018 pukul 18.00 UTC hingga 29 April 2018 pukul 00.00 UTC menjadi sebesar $10-30 \mathrm{~m} / \mathrm{s}$.

\subsection{Vortisitas}

Vortisitas didefinisikan sebagai banyaknya vektor kecepatan angin yang berotasi di suatu titik[2]. Semakin tinggi nilai mutlak vortisitas maka semakin besar vektor angin yang berotasi. Pada Belahan Bumi Selatan (BBS), vortisitas negatif menunjukan adanya aliran siklonik yang mengakibatkan terbentuknya awan konvektif. Sedangkan, pada Belahan Bumi Utara (BBU), aliran siklonik ditunjukkan pada nilai vortisitas positif. Berdasarkan Gambar 10, vortisitas lapisan $850 \mathrm{mb}$ di wilayah pembentukan siklon tropis bernilai -8 sampai $-10 \mathrm{x}$ $10^{-5} / \mathrm{s}$. Hal ini mengindikasikan aliran siklonik yang kuat di wilayah siklon tropis Flamboyan. Aliran siklonik ini akan terus naik didukung dengan adanya kecepatan vertikal, dimana akan terbentuk awan- wan konvektiv yang dpaat menyebabkan cuaca buruk.

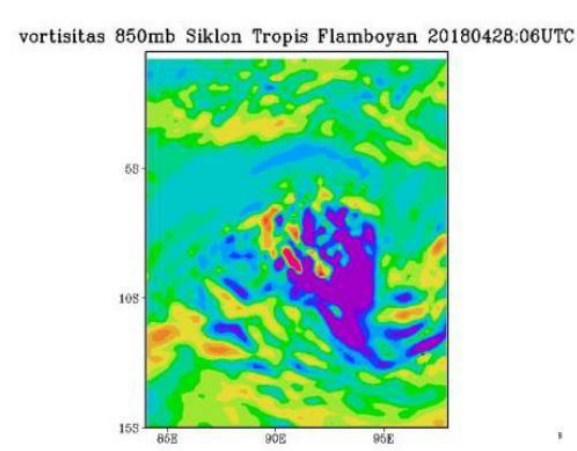

vortisitas 850mb Siklon Tropis Flamboyan 20180428:18UTC

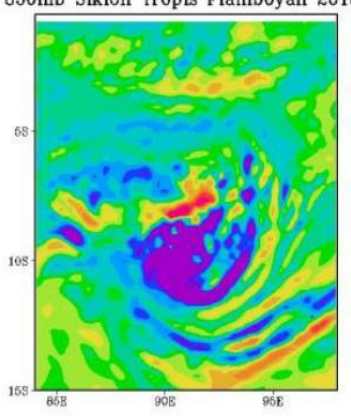

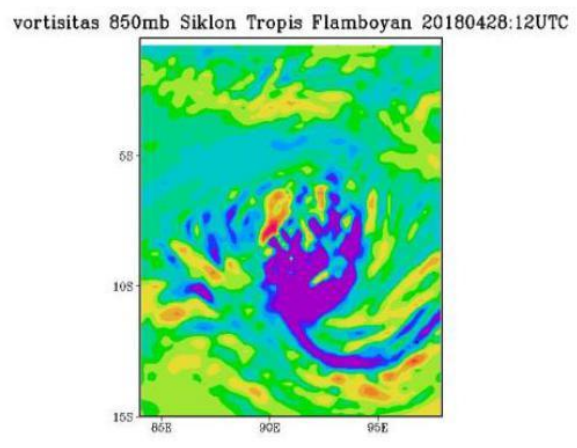

vortisitas 850mb Siklon Tropis Flamboyan 20180429:00UT

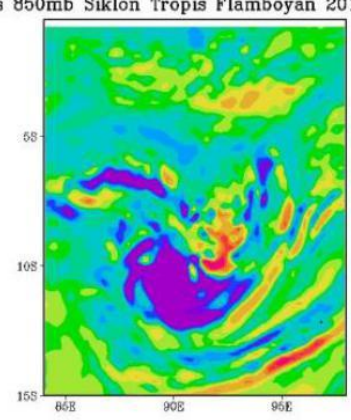

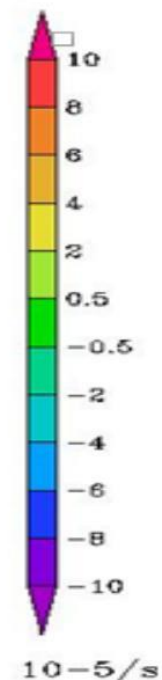

$10-5 / s$

Gambar 10. Vortisitas lapisan $850 \mathrm{mb}$ tanggal 28 April 2018 pukul 06.00 UTC hingga tanggal 29 April 2018 pukul 00.00 UTC

Pada Gambar 11 juga terlihat nilai vortisitas dari tanggal 28 April 2018 pukul 06 UTC hingga 29 April 2018 pukul 00 UTC bernilai negatif sebesar bernilai - 
8 sampai $-10 \times 10^{-5} / \mathrm{s}$. Walaupun memiliki nilai vortisitas yang sama dengan lapisan $850 \mathrm{mb}$, tetapi luasan wilayah dengan vortisitas negatif lebih kecil. Hal ini menandakan bahwa spade lapisan $500 \mathrm{mb}$ kekuatan siklon tropis sudah mulai melemah.

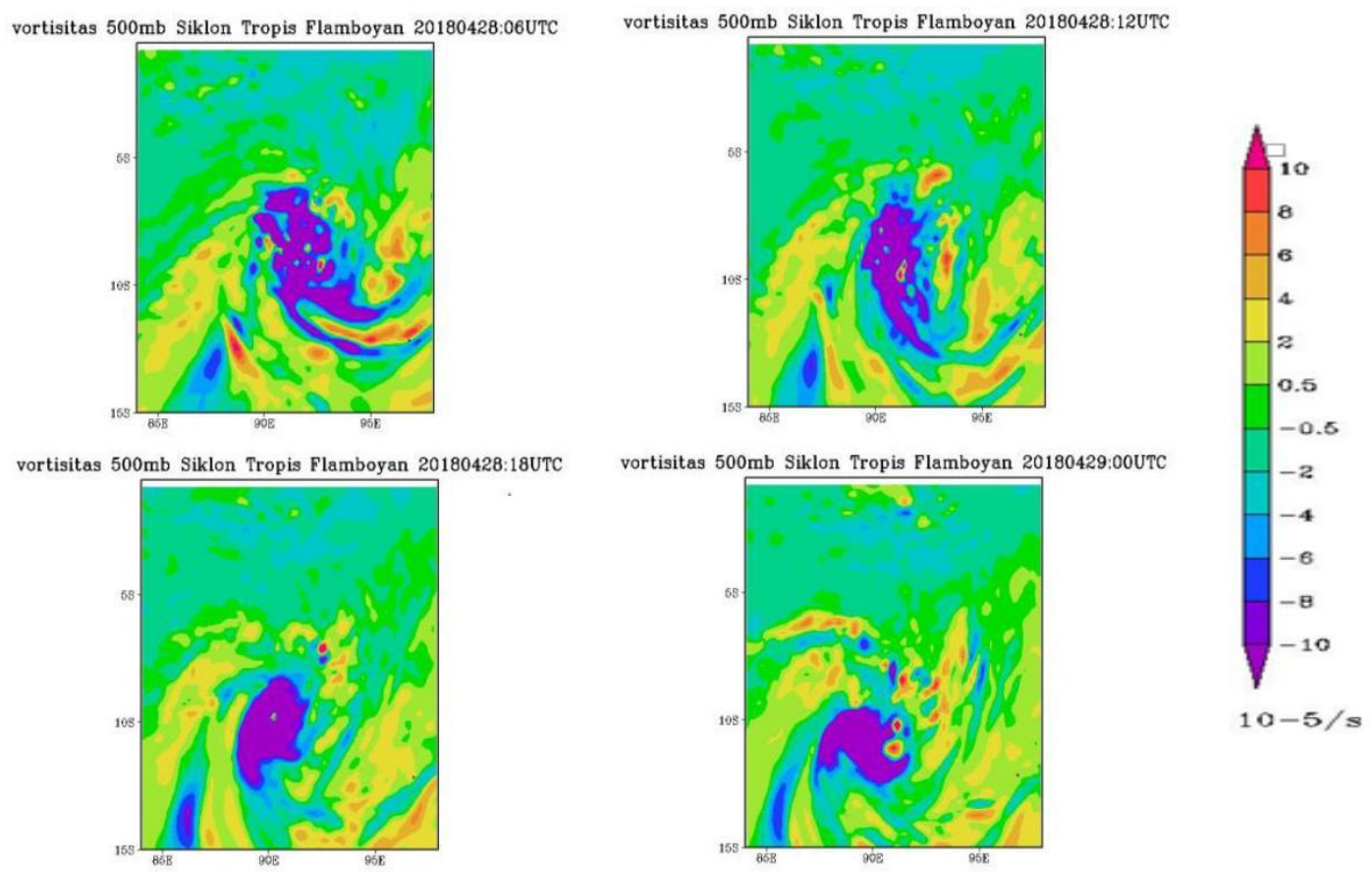

Gambar 11. Vortisitas lapisan 500 mb tanggal 28 April 2018 pukul 06.00 UTC hingga tanggal 29 April 2018 pukul 00.00 UTC

\subsection{Divergensi}

Divergensi merupakan suatu nilai yang menunjukkan ada tidaknya pertemuan massa udara. Jika nilai Divergensi negatif, maka menunjukkan bahwa di wilayah tersebut terjadi konvergensi. Pada Gambar 11 terlihat bahwa pada umumnya nilai divergensi lapisan $850 \mathrm{mb}$ di wilayah pembentukan siklon tropis bernilai negatif, berkisar anatara -6 hingga sampai $-10 \times 10^{-5} / \mathrm{s}$. Hal ini mengindikasikan bahwa ada area konvergensi atau pertemuan massa udara, sehingga mendukung pembentukan awan-awan konvektif yang dapat menyebabkan hujan lebat. Dari segi pola, juga terlihat bahwa di Gambar 12 terdapat pola melingkar dengan gerakan searah jarum jam.

Kemudian pada Gambar 12 menunjukkan divergensi lapisna 500 mb pada tanggal 28 April 2018 pukul 06 UTC hingga tanggal 29 April 2018 pukul 00 UTC masih bernilai negatif. Pola pada lapisan $500 \mathrm{mb}$ terlihat adanya nilai divergensi yang positif dan negatif secara selang seling, hal ini menunjukkan pada wilayah pembentukan siklon tropis Flamboyan, terjadi konvergensi pada dinding siklon dan divergensi di mata siklon. 
Divergensi 850mb Siklon Tropis Flamboyan 20180428:06UTC

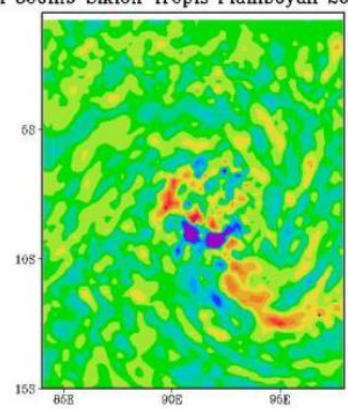

Divergensi $850 \mathrm{mb}$ Siklon Tropis Flamboyan 20180428:18UTC

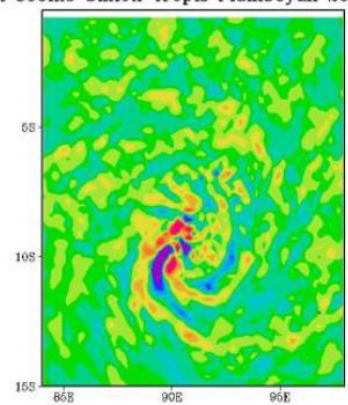

Divergensi 850mb Siklon Tropis Flamboyan 20180428:12UTC

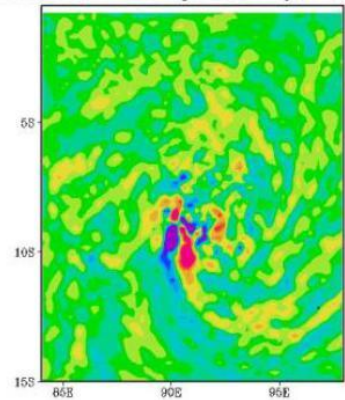

Divergensi $850 \mathrm{mb}$ Siklon Tropis Flamboyan 20180429:00UTC

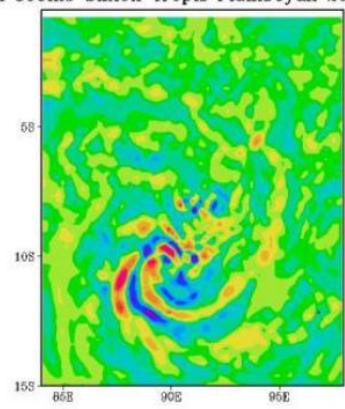

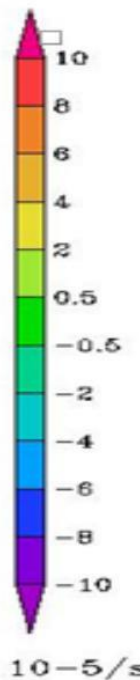

Gambar 12. Divergensi lapisan 850 mb tanggal 28 April 2018 pukul 06.00 UTC hingga tanggal 29 April 2018 pukul 00.00 UTC

Divergensi 500mb Siklon Tropis Flamboyan 20180428:06UTC

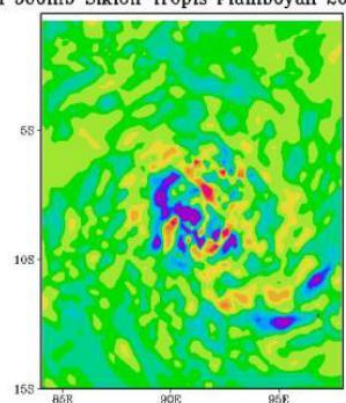

Divergensi 300mb Siklon Tropis Flamboyan 20180428:18UTC

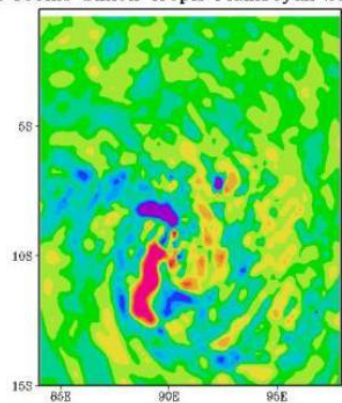

Divergensi 300mb Siklon Tropis Flamboyan 20180428:12UTC

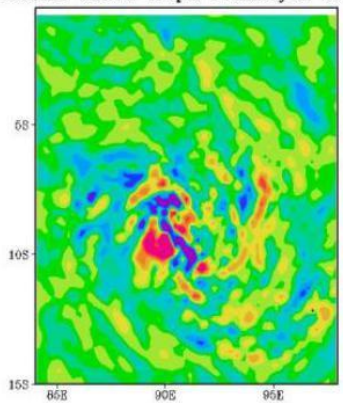

Divergensi 500mb Siklon Tropis Flamboyan 20180429:00UTC

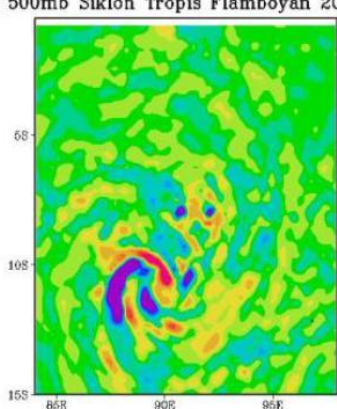

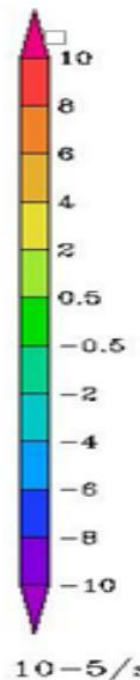

Gambar 13. Divergensi lapisan 500 mb tanggal 28 April 2018 pukul 06.00 UTC hingga tanggal 29 April 2018 pukul 00.00 UTC 


\section{Kesimpulan}

Siklon tropis merupakan salah satu fenomena yang memberikan dampak baik langsung maupun tidak langsung pada wilayah yang dilaluinya. Dampak yang ditimbulkan merupakan perubahan pola cuaca seperti angin kencang, gelombang tinggi maupun hujan lebat dimana apabila hadir dalam intensitas yang tinggi akan dapat menyebabkan kerugian baik jiwa maupun materil. Mengurangi kerugian akibat dampak dari siklon tropis yang ada, perlu adanya suatu metode yang akurat dalam memprediksi kehadirannya.

Hasil pengolahan data GFS menggunakan WRF-ARW untuk parameter yang digunakan dalam penelitian ini antara lain suhu permukaan laut, tekanan permukaan, kelembaban udara lapisan $850 \mathrm{mb}, 700 \mathrm{mb}$ dan $500 \mathrm{mb}$ serta streamline lapisan $925 \mathrm{mb}$ yang dioverlay dengan pola perawanan, vortisitas dan divergensi lapisan $850 \mathrm{mb}$ dan $500 \mathrm{mb}$ memberikan hasil yang mendukung dalam kehadiran siklon tropis Flamboyan yang ditandai dengan adanya pola sirkulasi tertutup pada tampilan spasial di setiap parameternya. Penggunaan data GFS dilakukan karena data tersebut merupakan data prediksi untuk parameter cuaca beberapa waktu kedepan.

Sehingga, dapat disimpulkan bahwa data GFS yang diolah menggunakan model WRF-ARW memberikan hasil yang cukup akurat dalam memprediksi kehadiran siklon tropis Flamboyan dimana, hasil ini dapat digunakan sebagai pedoman dalam memprediksi kehadiran siklon tropis kedepannya.

\section{Daftar Pustaka}

1. Ridwan, M. Kudsy.Parameterisasi Model Cuaca WRF-ARW Untuk Mendukung Kegiatan Teknologi Modifikasi Cuaca (TMC) di Sumatera, Sulawesi, dan Jawa. Jurnal Sains dan Teknologi Modifikasi Cuaca, Vol. 12 No.1 (2011) 1-8.

2. U.S. Department of Commerce - NOAA/NCEP. 2003. NCEP Office Note 442 - The GFS Atmospheric Model Description

3. BMKG, TCWC Jakarta. 2009. http://meteo.bmkg.go.id/siklon/learn (diakses 4 Juli 2018).

4. W. M. Gray, Tropical Cyclone Genesis. Colorado: Departement of Atmospheric Science (1975) Colorado State University

5. Seto, T. Handoko, Mengapa Hanya Sedikit Awan Konvektif Yang Tumbuh Di Atas Daerah Bandung Pada Periode 10 Desember 1999 S.D 04 Januari 2000. Jurnal Sains \& Teknologi Modifikasi Cuaca, Vol. 1 No.1 (2000) 61-66. 